\title{
РОЗВИТОК ПОЛІКУЛЬТУРНОЇ КОМПЕТЕНТНОСТІ МАЙБУТНІХ УЧИТЕЛІВ ЗАСОБАМИ ІНОЗЕМНИХ МОВ
}

Анотація. У статті трактовано ключове поняття «полікультурна компетентність майбутніх учителів іноземних мов». Виокремлено актуальність викладання гуманітарних дисциплін у закладах вищої освіти, зокрема іноземної мови. Мета дослідження полягає в теоретичному обгрунтуванні та експериментальній перевірці ефективності розроблених педагогічних умов розвитку полікультурної компетентності майбутніх учителів іноземних мов. Наукова новизна полягатиме в теоретичному обгрунтуванні поняття «полікультурна компетентність майбутніх учителів іноземних мов» та визначенні педагогічних умов, які сприятимуть формуванню полікультурної компетентності майбутніх учителів іноземних мов. Можна зробити висновок, що постає необхідність переглянути алгоритм роботи з мовними матеріалами, виділити в них культурний компонент, а лінгвістичні вправи доповнити культурологічними, що відкриває можливості подальшого дослідження теми.

Ключові слова: полікультурність, компетентність, майбутній учитель, іноземна мова.

Shkarlet Valeriia

«Luhansk Taras Shevchenko National University»

\section{DEVELOPMENT OF POLYCULTURAL COMPETENCE OF FUTURE TEACHERS BY MEANS OF FOREIGN LANGUAGES}

Summary. The article interprets the key concept of «multicultural competence of future foreign language teachers». The relevance of teaching the humanities in higher education institutions, in particular a foreign language, which expands the language skills of students and gives them the opportunity to become full members of a multicultural environment. The requirements that are now put forward for modern education to ensure the education of man and citizen, require the formation of the future specialist not only professional qualities, but also their own civic position. This approach is important for the training of professionals in any field, but it is most important for those who have to work in education. The complex and contradictory process of national revival requires a comprehensive understanding of the historical, political, social, ethnocultural determinants that determine the features of cultural and educational life of the state as a whole. The purpose of the study is to theoretically substantiate and experimentally test the effectiveness of the developed pedagogical conditions for the development of multicultural competence of future foreign language teachers. Methodology: to achieve this goal used theoretical research methods such as analysis of philosophical, psychological and pedagogical literature on the problem of research to determine the conceptual and categorical apparatus and consider the state of theoretical and practical development of the problem of forming multicultural competence of future teachers by foreign languages, as well as empirical methods: observation, interviews, questionnaires. Scientific novelty will consist in the theoretical substantiation of the concept of «multicultural competence of future teachers of foreign languages» and the definition of pedagogical conditions that will contribute to the formation of multicultural competence of future teachers of foreign languages. It can be concluded that there is a need to revise the algorithm of working with language materials, to highlight the cultural component, and linguistic exercises to supplement culturological, based on the culture of native speakers, which opens opportunities for further research.

Keywords: multiculturalism, competence, future teacher, foreign language.

$\prod^{\circ}$ остановка проблеми. Вимоги, що зараз висуваються до сучасної освіти по забезпеченню виховання людини та громадянина, потребують формування у майбутнього фахівця не лише профресійних якостей, але й власної громадянської позищії. Такий підхід є важливим для підготовки спеціалістів будь якого профілю, але найважливішим це $є$ для тих, кому належить працювати в сдері освіти.

У стратегічних законодавчих та освітніх документах нашої держави (Конституції України, законах «Про загальну середню освіту», «Про вищу освіту», Національній доктрині розвитку освіти та ін.) декларуються принципи багатоетнічності та полікультурності, ставляться завдання, спрямовані на розвиток фундаментальної підготовки майбутнього вчителя на основі засвоєння духовної скарбнищі українського народу, онтологічних, гностичних та аксіологічних компонентів цілісної полікультурної картини світу. У зв’язку 3 цим особливого значення набуває розвиток духовності майбутнього вчителя, що передбачає формування у нього духовних потреб, засвоєння універсальних духовних цінностей, орієнтованих на гуманістичні та демократичні ідеї. Цей процес пов'язаний з формуванням полікультурного світогляду, що зумовлюе таку організацію життя і профресійної діяльності, за якої педагог має бути відкритим до сприйняття культур інших народів. Національне при цьому набуває ознак Iрунтовності, оскільки полікультурний соціальний, зокрема й освітній простір, має фрункціо-

${ }^{1}$ ORCID: https://orcid.org/0000-0002-2958-6557 
нувати як цілісна система полілогу культур як на загальнодержавному рівні, так і їі окремих регіонів. Разом з цим зазначимо, що за роки незалежності Української держави було створено сприятливі умови для відродження системи освіти національних меншин, що потребуе вдосконалення професійної педагогічної освіти з урахуванням полікультурних особливостей.

Актуальність дослідження. Складний і суперечливий процес національного відродження потребуе всебічного осмислення історичних, політичних, соціальних, етнокультурних детермінант, що визначають особливості культурно-освітнього життя держави загалом; стає необхідним створення і налагодження конкретного механізму, у якому б етнічна самосвідомість виступала важливим чинником усвідомлення причетності до рідної етнічної культури, розуміння ії значення в консолідації української нації, у фрормуванні iï національно-державних інтересів.

Аналіз останніх досліджень вітчизняної педагогіки засвідчує, що в теорії та практиці профресійної освіти накопичено значний досвід, прогресивні ідеї якого можуть стати основою модернізації профресійної підготовки майбутніх учителів до міжкультурної взаємодії суб'єктів освітнього процесу. Крім того, виявлено провідні тенденції у цій сорері, обгрунтовано сучасні наукові підходи та парадигми. Зарубіжною педагогічною наукою вже накопичено значний досвід у розробці питань полікультурної освіти. Пращі низки зарубіжних науковців (Г. Бейкер, Дж. Бенкс, К. Бенкет, П. Вебер, Ж. Гей, Д. Голлнік, Дж. Іудлед, О. Джуринський, К. Кемпбел, В. Міттер, Т. Рюлькер, С. Ньєто, Е. Холлінс та ін.) стосуються запровадження полікультурної освіти, розробки концепції, моделі такої освіти тощо. Вивчення теоретичних засад та можливостей практичної реалізації полікультурного виховання в навчально-виховному процесі стало одним i3 найактуальніших напрямків вітчизняної педагогіки наприкінці XX - на початку XXI століть. В Україні проблема полікультурної освіти і виховання молоді є об'єктом уваги таких дослідників, як Е. Антипова, В. Бойченко, В. Болгарінова, Л. Волик, Л. Голік, О. Гуренко, Л. Горбунова, О. Ковальчук, О. Локшина, І. Лощенова, Л. Пуховська, А. Солодка, О. Сухомлинська та інших.

Невирішені частини загальної проблеми. Аналіз наукових джерел та стану полікультурної підготовки у вищій освіті в умовах впровадження світових стандартів ступеневої освіти в Україні свідчить про недостатню вивченість у вітчизняній педагогіці питання фрормування полікультурної компетентності студентів засобами іноземних мов. Тому метою нашої статті є обгрунтувати важливість оволодіння навичками полікультурної компетентності та висвітлити умови й засоби формування полікультурного компетента в процесі вивчення іноземних мов студентами ВНЗ. Усе це передбачає розв'язання таких завдань: дослідити сутність поняття «полікультурна компетентність», розкрити структурні компоненти та методи реалізації даного феномена засобами іноземних мов.

Постановка завдання. В контексті нашої науково-практичної роботи, ми вважаємо за доцільне визначити ступінь дослідженості обра- ної нами проблеми у вищій освіті та означити, як в сучасній педагогічній науці трактують одне 3 ключових понять нашого дослідження "полікультурна освіта». Головним завданням постає: по-перше, уточнити сутність та зміст понять «полікультурна освіта" та "полікультурність»; по-друге, встановити взаємозв'язок між зазначеними вище поняттями; по-трете, розкрити їх вплив на процес профресійної підготовки майбутніх учителів іноземних мов.

Виклад основного матеріалу. Полікультурність - процес входження людини в іншу культуру, занурення в культурну своєрідність через розвиток особистої культури. В свою чергу «полікультурна освіта» - це пізнання особистістю полікультури, можливість самореалізації в полікультурному світі, що сприяе безконфрліктній їі ідентифікації в багатокультурному суспільстві та інтеграції в полікультурний світовий простір. Г.С. Абібулаєва підкреслюе, що полікультурна освіта направлена на збереження й розвиток усього різноманіття культурних цінностей, норм i форм діяльності, існуючих у суспільстві, та базується на взаємодії різних культур [1, с. 78]. Полікультурна освіта $є$ важливим механізмом залучення молоді до всебічного пізнання культури свого народу; формування уявлень про розмаїття культур у світі; навчання позитивного ставлення до культурних розходжень; виховання в дусі миру, толерантності, гуманного міжнаціонального спілкування. Провідною фрункцією полікультурної освіти, таким чином, виступає dpopмування особистості, готової працювати в умовах поліетнічного, багатокультурного середовища, орієнтованої на конструктивну взаємодію та діалог 3 носіями різних культур.

Загалом, сучасна полікультурна освіта має будуватися на основі врахування таких основних принципів: діалектичної включеності національної культури в систему української та світової; історико-культурної та цивілізащійної спрямованості національної освіти, що допускає необхідність розкриття історичної обумовленості явищ минулого i сьогодення, вивчення фольклору, національного мистецтва, звичаїв і традицій; полікультурної ідентифрікації та самоактуалізації особистості; глобальності культурно-освітнього процесу, відповідального за розвиток цілісного полікультурного світогляду; полікультурної толерантності та інтеросвітньої перспективи, що відображає механізм етнокультурної ідентифікації особистості до структури гармонізації міжетнічних відносин.

Відповідно, як вважае Л. Столярчук, полікультурну освіту можна визначити як особливий образ мислення, заснований на ідеях свободи, справедливості, рівності; освітня редорма, нащілена на перетворення традиційних освітніх систем 3 тим, щоб вони відповідали інтересам, освітнім потребам і можливостям учнів незалежно від расової, етнічної, мовної, соціальної, гендерної, релігійної, культурної приналежності; міждисциплінарний процес, який пронизуе зміст всіх дисциплін навчальної програми; методи і стратегії навчання; взаємовідношення між всіма учасниками навчально-виховного середовища; процес залучення вихованців до багатства світової культури через послідовне засвоєння знань про 
рідну і загальнонаціональну культури; озброєння майбутніх фрахівців умінням критично аналізувати будь-яку інформацію, щоб уникати помилкових висновків; формування толерантного ставлення до культурних відмінностей [8, с. 96].

В умовах полікультурної реальності особливої актуальності набуває викладання гуманітарних дисциплін у ВНЗ, зокрема іноземної мови, адже вивчення окремої мови розширює культурні знання студентів, даючи їм можливість стати повноправними членами полікультурного середовища. Як зазначає Д. Фурт, «кожен урок іноземної - це перехрестя культур, це практика міжкультурної комунікації, тому що кожне слово відображае іноземне середовище та іноземну культуру: за кожним словом обумовлене національною свідомістю уявлення про світ» [9, с. 245].

При навчанні іноземних мов фрормуванню та розвитку полікультурного компонента професійної компетентності майбутніх учителів, на нашу думку, сприятиме конструктивний відбір навчального матеріалу; оптимальна організація системи занять 3 профресійної науково-предметної підготовки (використання кооперативного та інтерактивного навчання); широке залучення студентів до громадської діяльності на фракультеті, в університеті, до роботи в соціальних програмах, міжнародних проектах, передвиборчих кампаніях тощо. Як один 3 компонентів компетентності майбутніх учителів іноземних мов ми розглядаємо полікультурну компетентність. Сучасний учитель повинен одночасно усвідомлювати себе носієм національних цінностей i мати планетарне мислення. За своєю природою - це новий погляд на світ, його проблеми, можливі шляхи їх вирішення, боротьба за виживання людства, збереження довкілля, шлях до миру й благоденства, відмова від застарілих стереотипів і норм, від усіх видів егоїзму. Це мислення, спрямоване на усвідомлення цілісного, взаємопов'язаного та взаємозумовленого світу.

Під поняттям полікультурна компетентність ми розуміємо сукупність соціокультурних знань; навичок і вмінь позитивної міжетнічної комунікації; особистісних якостей та гуманістичних цінностей, необхідних для ефективної життедіяльності в полікультурному середовищі. Полікультурна компетентність сприяе формуванню у студентів полікультурної світоглядної позиції, яка передбачає визнання рівноцінності інших культурних, мовних, релігійних уподобань, виховання, завдяки правильному добору іншомовного навчального матеріалу, толерантного ставлення до них, розвиток особистості, здатної до міжкультурної взаємодії, діалогу культур [3, с. 41].

Необхідність формування в майбутніх учителів полікультурної компетенції пов язана 3 тим, що на початку XXI століття все більш нагальною постає проблема мирного співіснування й продуктивного співробітництва людей різних націй, віросповідань, прибічників різноманітних стилів життя, представників різних культур, тобто проблема діалогу культур. Тенденції розвитку світового співтовариства свідчать про те, що у глобальному масштабі єдиним шляхом до прогресу людства є інтеграція на рівні виробництва, споживання, формування національної самосвідомості, розвитку міжкультурних зв'язків.
Сучасна концепція іншомовної освіти базуеться на інтегрованому навчанні мові та культурі країни, мова якої вивчаеться, на діалозі рідної та іноземної культур. Мета такої освіти - навчання мови - через культуру, культури - через мову. Як зазначається у проекті Ради Свропи: «Навчання іноземної мови для європейської громади необхідно для полегшення вільного пересування людей, інформації та ідей в Свропі з метою побудови взаєморозуміння та сприйняття культурного й мовного розмаїття в багатомовній та багатокультурній Європі та виховання поваги до національного самовизначення» [10, с. 202].

Основним джерелом індормації полікультурної спрямованості виступають автентичні матеріали, що своїм змістом розкривають певні аспекти проблеми з позицій іншої культури. У світлі формування полікультурної компетентності важливе значення мають урізноманітнення занять 3 іноземної мови матеріалами країнознавчої спрямованості (історія, звичаї, традищї, свята, політичний устрій, визначні місця, визначні діячі мистецтва й науки країн, мова яких вивчається, тощо); включення до їх змісту уривків літературних творів і публіцистичних матеріалів, у яких культивуються загальнолюдські цінності; постановка завдань на зіставлення культурних відмінностей України та країн, мова яких вивчаеться (проекти, повідомлення, презентащії) тощо.

М. Денисенко класифрікуе навчальні вправи щодо формування полікультурної компетентності чотирьох типів: рецептивні, рецептивно-репродуктивні, рецептивно-продуктивні та продуктивні або творчі. Вправи рецептивного типу - це власне читання текстів культурно-країнознавчої тематики. Рецептивно-репродуктивний тип використовуеться для усунення лексичних і граматичних труднощів, формування прогностичних навичок та вмінь, а також для розширення культурно-країнознавчого кругозору студентів. Виконуючи щі вправи, студенти мають зрозуміти й відтворити або доповнити подану культурологічну інформацію в ситуаціях іншомовної комунікації. Рецептивнопродуктивні вправи спрямовані на виховання самостійності, ініціативності особи, що виявляеться через прагнення зрозуміти й оцінити інформацію, розпізнати зв'язки, що існують між новими і вже відомими культурними явищами, знайти нестандартні шляхи вирішення тих чи інших проблем. Продуктивні або творчі вправи розвивають критичне мислення учасників навчання, їхню пізнавальну активність та самостійність у розв'язанні навчальних завдань і позанавчальних ситуацій [5, с. 16-17].

Значно сприятиме формуванню полікультурної компетенції студентів використання інтерактивних методів та інноваційних технологій. Зокрема, застосування мультимедійних засобів не тільки підвищує мотивацію та створюе творчу атмосфреру, а й демонструе необмежені можливості компютерних технологій, які допомагають вирішити багато навчальних проблем, а саме: організації пізнавальної діяльності, імітації типових ситуацій спілкування засобами мультимедія, застосування отриманих знань у нових ситуаціях, ефрективного тренування засвоєних умінь та навичок, автоматизованого контролю результатів навчання, можливості поєднання візуальної 
та звукової фрорм навчання мови. Систематичне використання аудіо-візуальних та інтерактивних засобів, таких як інтернетпрограми, презентації, відеоролики, ресурси мережі Інтернет, навчальні, документальні, художні фрільми, значно підвищуе ефрективність навчання, стимулюе цікавість до вивчення мов, гуманного міжнаціонального спілкування та формування вмінь і навичок конструктивної взаємодії з носіями різних культур. Проведення конференцій, лінгвокраїнознавчих вікторин, віртуальних екскурсій, дебатів, диспутів, творчих конкурсів, мовних тижнів, днів національної культури, олімпіад, проектів країнознавчого характеру сприяе розвитку у студентів уміння міжкультурної комунікації та вирішення конфрліктів, які мають за мету виховувати поважливе ставлення до іншої думки, сприйняття різнодумства всередині групи як позитивного явища, розуміння важливості існування різних підходів до вирішення проблеми.

Центральне місце в навчанні іноземних мов поряд 3 отриманням лінгвокультурологічних знань займає розвиток у молоді здатності до полікультурного спілкування, тобто до адекватного взаєморозуміння двох і більше учасників комунікативного акту, які належать до різних нащіональних культур [7, с. 150]. Міжкультурний компонент спілкування - явище багатогранне та спрямоване на внутрішні (спілкування між представниками різних етнічних груп у межах полікультурної держави) і зовнішні (спілкування між представниками різних держав) відмінностей у ньому. Крім того, міжкультурні особливості спілкування охоплюють і міжнаціональні, тендерні, соціальні, демографрічні, мовні та інші відмінності.

Для організації міжкультурного спілкування на заняттях з іноземної мови необхідне створення навчальних комунікативних ситуацій, які визначають його умови й цілі та ставлять перед необхідністю навчити студентів позитивного підходу до іноземної мови, культури народу. Важливо визначити правильну лінію мовної поведінки в іншомовному середовищі на основі знань про особливості менталітету носіїв мови [2, с. 26]. 3 метою правильного й адекватного спілкування необхідно намагатися не перекладати інформацію дослівно, а знати, що і коли потрібно сказати в конкретній ситуації. Однією з неодмінних умов досягнення такого рівня спілкування іноземною мовою є, крім знання способу вираження думок носіями мови, уміння співвіднести ці особливості з нормами і звичними оборотами рідної мови. Для розвитку навичок зручно використовувати етикетну лексику, одночасно зіставляючи її з еквівалентами рідної мови, що дає студентам можливість адекватно вживати ту чи іншу лексичну одиницю. Завдання викладача іноземної мови в даному випадку не просто надати лексичні кліше, а й редрлексувати їх на рідну мову та проаналізувати частоту їх вживання в повсякденній рідній культурі.

При цьому не слід забувати про невербальну мову, використання якої може або підтверджувати вербальне повідомлення, або суперечити йому. Викладач повинен не пояснювати нову культурно-етикетну лексичну одиницю, а ввести iii відразу з невербальним повідомленням, яке властиво конкретній фрразі.
Спостереження, зіставлення різних прагматичних моментів тіеї чи іншої культури дозволяе бачити в них не лише відмінності, але й подібності. Адже головним завданням полікультурної освіти засобами іноземної мови $є$ фрормування й поглиблення уявлення не тільки про специфрічні відмінності в культурах, а й про їх загальні риси в глобальному сенсі. Важливість формування полікультурної компетентності в майбутніх учителів іноземної мови зумовлена передусім високим покликанням учителя бути координатором ціннісного розвитку учнів взагалі та змістом предмета, що викладається, зокрема. Оскільки процес оволодіння іноземною мовою передбачає не лише обізнаність у мовних, мовленневих механізмах, а й знання культурних особливостей країни, мова якої вивчаеться [6, с. 32]. Процес навчання іноземної мови веде не лише до пізнання культури, мова якої вивчається, але і до поглиблення знань про культуру власного народу через осмислення чужої.

У закладах вищої освіти діалог культур реалізуеться через міжкультурний компонент іноземної мови, що не тільки створюе найкращі умови для виховання в студентів визнання розбіжностей у своїй і чужих культурах та поважного ставлення до них, але й допомагає пробудити почуття гордості за свою країну, народ, культуру. Міжкультурний компонент іноземної мови сприяе формуванню в студентів уявлення про діалог культур як про єдину можливу в сучасних полікультурних спільнотах фрілософрію існування, яка відрізняеться етнічною, расовою, соціальною та релігійною толерантністю до представників інших культур. У практичному плані вміло використаний міжкультурний компонент іноземної мови сприяе формуванню позитивного ставлення студентів до представників інших культурних груп та налаштованості на ненасильницьке вирішення спірних проблем, співпрацю і взаєморозуміння.

Майбутньому вчителю іноземних мов O.I. Гуренко відводить роль "медіатора культур» - спеціаліста 3 міжкультурної комунікації, посередника між культурами (культурою своєї країни та культурою країни, мова якої вивчається), який володіє іноземною мовою як особливістю культури [4, с. 101]. Тому будь-які знання, що здобуваються за допомогою іноземної мови, будуть сприйматися тільки через призму знань, сdpopмованих у процесі оволодіння рідною культурою. Навчати культури країни досліджуваної мови

означає вчити дізнаватися, розуміти, оцінювати пріоритети іншого народу.

Вищесказане свідчить про те, що полікультурна освіта повинна стати сьогодні для школи однією 3 пріоритетних, а здійснювати їі покликані вчителі зі сорормованим полікультурним мисленням. Безумовно, особливе місце в цьому процесі посідає вчитель іноземних мов у зв язку 3 тим, що у специфіці його предмету закладені змістовні можливості полікультурної освіти.

На нашу думку, ознаками сформованості полікультурної компетентності є: сфрормоване світосприйняття студентів; усвідомлення себе носіями національних цінностей; розуміння взаемозалежності між собою та всіма людьми; розвинута комунікативна культура студентів, а саме, знання етики дискусійного спілкування й вза- 
ємодії з людьми, які дотримуються інших поглядів, віросповідань, 3 представниками інших культур; загальнопланетарний спосіб мислення; толерантність, повага до мови, релігії, культури різних націй.

Оскільки підготовка майбутніх учителів іноземних мов має за мету комплексну реалізацію практичної, виховної, освітньої та розвиваючої цілей, слід розглянути, які зміни матимуть місце при їх реалізації в умовах полікультурної освіти. Так, виховна мета може бути інтерпретована 3 наступних позицій: оріентація на гуманізацію освіти; навчання у дусі діалогу культур; виховання взаєморозуміння й терпіння щодо інших культур, здатності ставитися до них з повагою; прояв інтересу до контакту з іншими культурами.

Тлумачення освітньої мети може бути доповнене більш глибоким засвоєнням рідної культури через зіткнення 3 іншою культурою та взаемодію 3 нею, а також розширенням мовного, соціального та інтелектуального кордону тих, хто навчається.

Досягнення розвиваючої цілі навчання передбачае: розвиток уміння проникати в культуру країни, мова якої вивчається, під час зіткнення суспільних, культурних і мовних реалій, вико- ристовувати соціокультурний фон для розуміння й тлумачення соціокультурних елементів, розуміти приналежність до національного і світового співтовариства, формулювати власну точку зору; розвиток здатності орієнтуватися в ціннісних категоріях власного та чужого суспільства.

Висновки та пропозиціі. Отже, формування полікультурної компетентності майбутніх учителів іноземних мов в процесі вивчення іноземних мов базуеться на поєднанні процесів оволодіння лінгвістичними аспектами мови 3 культурологічними знаннями, що сприяе накопиченню необхідних для ефективної міжкультурної комунікації полікультурних знань та становленню особистісних якостей молоді, здатної не лише адекватно реагувати на прояви іншої культури та виявляти готовність до міжкультурної взаємодії в поліетнічному середовищі, а й виступати носіем, зберігачем і ретранслятором кращих зразків рідної, української та світової культур. Тому постає необхідність переглянути алгоритм роботи 3 мовними матеріалами, виділити в них культурний компонент, а лінгвістичні вправи доповнити культурологічними, заснованими на культурі носіїв мови, що відкриває можливості подальшого дослідження теми.

\section{Список літератури:}

1. Абібулаєва Г.С. Деякі аспекти полікультурної освіти. Педагогіка і психологія . 2006. № 1. С. $75-84$.

2. Агадуллін Р. Полікультурна освіта: методолого-теоретичний аспект. Педагогіка і психологіл. 2004 . № 3. С. $25-27$.

3. Бориско Н.Ф. Діалог культур: необхідність, можливість і межі. Інозелині лови. 2003. № 2. С. 77-81.

4. Гуренко O.І. Полікультурна освіта майбутніх соціальних педагогів як педагогічна система. Наукові записки Бердянського держ. пед. ун-ту. Серія : педагогічні науки. 2016. Вип. 2. С. 99-106.

5. Денисенко М.В. Формування в учнів старшої школи полікультурної комунікативної компетенції бачить у читанні англомовних культурно-країнознавчих текстів. Іноземні мови. 2007. № 2. С. 16-22.

6. Кузьменко В.В., Гончаренко Л.А. Формування полікультурної компетентності вчителів загальноосвітньої школи : Навчальний посібник. Херсон : РІПО, 2006. 92 с.

7. Хомич Л.О. Полікультурна освіта в контексті загальнокультурного розвитку особистості педагога : монографрія / за ред. Л.Ю. Султанова, Т.О. Шахрай. Кіровоград : Імекс-ЛТД, 2014. 212 с.

8. Столярчук Л. Формування полікультурної компетентності студентів у процесі вивчення іноземних мов. Обрії. 2014. № 1(38). С. 95-99.

9. Фурт Д. Феномен полікультуралізму в педагогічному дискурсі. Педагогіка вищої та середньої школи. 2014. Вип. 40. С. 244-249.

10. Modern Language Learning, Teaching, Assessment // A Common European Framework of Reference / Council of Europe, Education Committee. Strasbourg, 2008. 224 p.

\section{References:}

1. Abibulaieva H.S. (2006) Deiaki aspekty polikulturnoi osvity [Some aspects of multicultural education]. Pedahohika i psykholohiia, vol. 1 , pp. 75-84.

2. Abibulaieva H.S. (2006) Deiaki aspekty polikulturnoi osvity [Multicultural education: methodological and theoretical aspect]. Pedahohika i psykholohiia, vol. 3, pp. 25-27.

3. Borysko N. F. (2003) Dialoh kultur: neobkhidnist, mozhlyvist i mezhi [Dialogue of cultures: necessity, opportunity and limits]. Inozemni movy, vol. 2, pp. 77-81.

4. Hurenko O.I. (2016) Polikulturna osvita maibutnikh sotsialnykh pedahohiv yak pedahohichna systema [Multicultural education of future social educators as a pedagogical system]. Naukovi zapysky Berdianskoho derzh. ped. un-tu. Seriia: pedahohichni nauky, vol. 2, pp. 99-106.

5. Denysenko M.V. (2007) Formuvannia v uchniv starshoi shkoly polikulturnoi komunikatyvnoi kompetentsii bachyt u chytanni anhlomovnykh kulturno-krainoz navchykh tekstiv [Formation of multicultural communicative competence in high school students is seen in reading English-language cultural and regional educational texts]. Inozemni movy, vol. 2, pp. 16-22.

6. Kuzmenko V.V.(2006) Formuvannia polikulturnoi kompetentnosti vchyteliv zahalnoosvitnoi shkoly: Navchalnyi posibnyk [Formation of multicultural competence of secondary school teachers: Textbook]. Kherson: RIPO. (in Ucranian)

7. Polikulturna osvita v konteksti zahalnokulturnoho rozvytku osobystosti pedahoha (2014): monohrafiia [Multicultural education in the context of general cultural development of the teacher's personality: monograph]. Kirovohrad: Imeks-LTD.

8. Stoliarchuk L. (2014) Formuvannia polikulturnoi kompetentnosti studentiv u protsesi vyvchennia inozemnykh mov [Formation of multicultural competence of students in the process of learning foreign languages]. Obrii, vol. 1 , no. 38 , pp. $95-99$.

9. Furt D. (2014) Fenomen polikulturalizmu v pedahohichnomu dyskursi [The phenomenon of multiculturalism in pedagogical discourse]. Pedahohika vyshchoi ta serednoi shkoly, vol. 40, pp. 244-249.

10. Modern Language Learning, Teaching, Assessment // A Common European Framework of Reference / Council of Europe, Education Committee. Strasbourg, 2008. 224 p. 